\title{
THE TESTING OF OILS WITH THE OLEO-REFRACTOMETER.
}

By Thomas H. Pearmain.

(Read at the Meeting, April 3, 1895.)

Now that the oleo-refractometer, as devised by Messrs. Jean and Amagat, is coming so largely into use in commercial work, the following table, which gives a summary of the results of the examination of 240 samples of oil, may be of interest.

I find much better results are obtained with this instrument when the temperature is falling, especially in the case of butter and margarine, which, owing to their higher melting-point, have to be observed at the higher temperature, namely, $45^{\circ} \mathrm{C}$.

If the sample of oil under examination is very acid, it is necessary to remove the free fatty acid by shaking the oil in a separator with hot alcohol, after which treatment the oil is dried at $105^{\circ} \mathrm{C}$.

In testing oils which give a high deviation, as the fish oils, for instance, it is desirable when making the observation to dilute them with their own volume of lardoil, whereby a much sharper shadow is obtained. The figure so obtained is, of course, doubled to obtain the proper refraction number of the oil. 


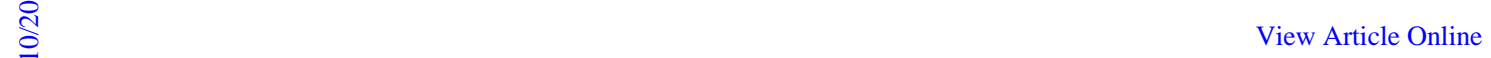

It is to be regretted that the oleo-refractometer is not a more satisfactory test in the case of butter and margarine. My results confirm those of G. H. Ellinger (THE ANalyst, 1891, p. 197), who tested 510 samples of Danish butter, and found the greatest difference of deviation to be from $35^{\circ}-23^{\circ}$ when examined in this instrument at $45^{\circ} \mathrm{C}$.

\begin{tabular}{|c|c|c|c|c|c|c|c|c|c|c|c|}
\hline $\begin{array}{c}\text { Temperature } \\
22^{\circ} \mathrm{C} \text {. }\end{array}$ & 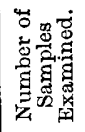 & 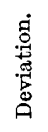 & $\begin{array}{l}\text { 莺 } \\
\text { :0 } \\
\overrightarrow{80} \\
\vec{z}\end{array}$ & 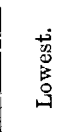 & 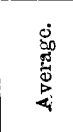 & $\begin{array}{c}\text { Temperature } \\
22^{\circ} \mathrm{C}\end{array}$ & 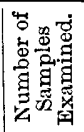 & 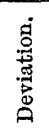 & 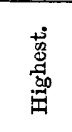 & $\begin{array}{l}\text { 范 } \\
\text { 总 } \\
\text { 号 }\end{array}$ & 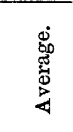 \\
\hline 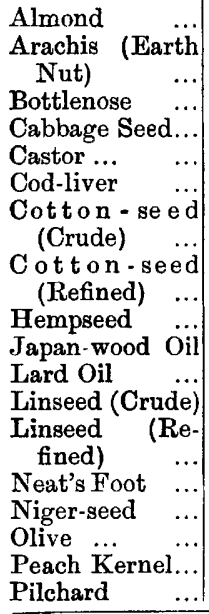 & $\begin{array}{r}6 \\
4 \\
1 \\
6 \\
3 \\
\\
5 \\
2 \\
2 \\
105 \\
2 \\
2 \\
\end{array}$ & $\begin{array}{l}+ \\
+ \\
+ \\
+ \\
+ \\
+\end{array}$ & $\begin{array}{r}54 \cdot 0 \\
3 \cdot 0 \\
30.0 \\
3.5 \\
11.5 \\
36.0 \\
\end{array}$ & $\begin{array}{r}8 \cdot 0 \\
5 \cdot 0 \\
50 \cdot 0 \\
15 \cdot 0 \\
39 \cdot 0 \\
40 \cdot 0\end{array}$ & $\begin{array}{r}9.5 \\
6.0 \\
50.0 \\
15 \cdot 0 \\
40.0 \\
44.0\end{array}$ & $\begin{array}{ll}\text { Poppy-seed } & . . \\
\text { Rape ... } & . . \\
\text { Ravison } & . . \\
\text { Seal } & . . \\
\text { Sesamé } & . . \\
\text { Shark ... } & . \\
\text { Sunflower } & . \\
\text { Tallow Oil } & . \\
\text { Tea } & . . \\
\text { Whale ... } & . . \\
\text { Oleic Acid } & . . \\
\end{array}$ & $\begin{array}{l}3 \\
8 \\
2 \\
2 \\
5 \\
3 \\
1 \\
2 \\
1 \\
1 \\
2 \\
3\end{array}$ & $\begin{array}{l}+ \\
+ \\
+ \\
+ \\
+ \\
+ \\
+ \\
+ \\
+ \\
+\end{array}$ & $\begin{array}{r}35 \cdot 0 \\
20 \cdot 0 \\
24 \cdot 0 \\
36 \cdot 0 \\
17 \cdot 0 \\
35 \cdot 0 \\
35 \cdot 0 \\
5 \cdot 0 \\
5 \cdot 0 \\
48 \cdot 0 \\
33 \cdot 0\end{array}$ & $\begin{array}{r}30 \cdot 0 \\
16 \cdot 0 \\
20 \cdot 0 \\
30 \cdot 0 \\
13 \cdot 0 \\
29 \cdot 0 \\
35 \cdot 0 \\
1 \cdot 0 \\
8 \cdot 0 \\
42 \cdot 0 \\
29 \cdot 0\end{array}$ & $\begin{array}{r}33 \cdot 0 \\
17 \cdot 5 \\
22 \cdot 0 \\
33 \cdot 0 \\
15 \cdot 5 \\
31 \cdot 0 \\
35 \cdot 0 \\
30 \\
8 \cdot 0 \\
45 \cdot 0 \\
32 \cdot 0\end{array}$ \\
\hline
\end{tabular}

\section{Discussion.}

Mr. Bevan said that it was his practice to examine with the oleo-refractometer every sample of butter passing through his hands, and he had never found it lead to a mistake. Its working, however, depended to some extent upon the personal element, as well as upon the exact position of the prism, and there might be differences between the results of different observers using different instruments.

He suggested a mixture of glycerine and water as a substitute for the standardizing oil supplied with the instrument. It would be much cheaper, and would be free from the disadvantage of being only obtainable in Paris.

He took exception to the use of the term " refractive index," which he thought might convey misleading ideas.

Mr. AlLEn agreed with Mr. Bevan as to the usefulness of the instrument. He thought, however, that the price charged for it was a great deal too high. He had reason to believe that the angle of the prism was not strictly the same in all instruments, and this would account for some of the discrepancies to be found among the results of different operators. But a sample of lard, which showed $4 \frac{1}{2}^{\circ}$ in his own instrument, gave $6^{\circ}$ in Mr. Bevan's and $11^{\circ}$ in that of another well-known analyst, all these observations being made by Mr. Allen personally. This state of things was a disgrace to the manufacturers of the instrument. 


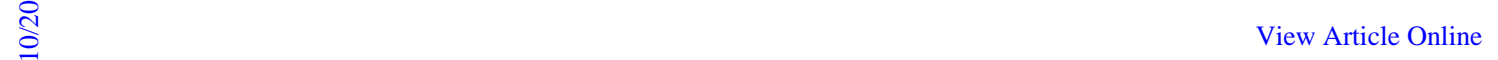

The Chairman questioned whether the oleo-refractometer afforded any more information than could be obtained from the iodine absorption test. The figures given in the paper seemed to him to show that oils of high iodine absorption also had a high refractive power, and that the latter stood in direct proportion to the iodine absorption. If this was really the case, he thought the iodine absorption test was much to be preferred. 